\title{
List of Narratives
}

The Origin of the Comunidad Chanchabac by an anonymous Chanchabac elder 33

Santiago and the Parcialidad Herrera by an anonymous Herrera elder 34

Entering the Service by Pedro Contreras 40

Tradition and Politics in the Cofradía of Santiago by fuan Ixc'oy 44

The Danger of Being of Two Hearts by Pablo Itzep 47

The Conquest Dance by Miguel Castillo 52

The Tzulab by fuan Ixc'oy 53

The Monkeys by Florentino Ixbatz 55

The Fiesta of the Niño by Pablo Itzep 68

The Image Gives Signs by Pablo Itzep 74

Signs at the Fiesta of Santa Isabel by Florentino Ixbatz $\quad 78$

Problems at the Fiesta by fuan Ixc'oy 80

The Fiesta in Pueblo Viejo by fuan Ixc'oy 81

Apparel for Santiago by fuan Ixc'oy 88

Santiago Teaches a Lesson by Florentino Ixbatz 90

The Patrón Gives Signs by fuan Ixc'oy 91

Patrón Santiago in Dreams by Florentino Ixbatz and Son 92

The Patrón's Women by fuan Ixc'oy 95

The Origins of the Native Altars by Florentino Ixbatz 98

Origin of the Altars by Domingo Castillo 99

The Story of the Monkeys Dance by Florentino Ixbatz 110

Dance Ritualists and Costumbre by Florentino Ixbatz 112

Calling the Animals from the Stone by Florentino Ixbatz 114

Erecting the Tree by Florentino Ixbatz 115

The Story of the Conquest Dance by Miguel Castillo 125 
Aj Itz by Miguel Castillo 135

The Meaning of the Conquest by Miguel Castillo 136

San Simón by fuan Ixc'oy 153

Visits to Maximons in Other Towns by fuan Ixc'oy 156

The Service of Corpus by Pedro Contreras 160

The Coastal Pilgrimage by Pedro Contreras 167

The Tzulab by fuan Ixc'oy 178 